\title{
NOTES ON THE PTERIDOPHYTES OF THE DUTGH WEST INDIES
}

\author{
K. U. KRAMER \\ (Botanical Museum and Herbarium, Utrecht)
}

(received May 9th, 1960)

The present paper is intended as an introduction to the author's treatment of the ferns and fern allies in Mr. A. L. Storfers' new Flora of the Netherlands Antilles, the first volume to be published shortly. Apart from phytogeographical notes that do not usually find a place in such a flora, in the following some nomenclatural notes are given, besides a few explanatory remarks on the principles employed in the classification.

\section{TAXonomic Notes}

A. The system

In connection with the increased interest in fern taxonomy of the last decades several systems of classification have been proposed which, especially in the Leptosporangiate ferns, show no small degree of diversity. Though most of these systems contain definite elements of advance, it is felt that none of them has been sufficiently worked out in every respect to be acceptable as a whole. (The interested reader may find a review of these systems in Pichi-Sermolli, 1959). Consequently none of these systems has been entirely adopted for the treatment under consideration. With regard to the family treatment the author has been rather conservative and has maintained the Polypodiaceae in their old, inclusive circumscription; not because he believes that they are a natural entity, but because it seems to him that none of the various ways in which they have been subdivided is quite satisfactory.

On the generic level a more modern concept has been adopted. With regard to the genera recognized the writer finds himself in rather close agreeance with Proctor (1953). The Thelypteridoids, for instance, are treated as distinct from the Dryopteridoids, and Cyclosorus, Goniopteris, Meniscium, etc., have been united with Thelypteris (see also Morton, 1950). It seems that the differences between the Grammitidoid and the Polypodioid ferns have also been sufficiently demonstrated; but the author prefers to recognize at least provisionally the genus Xiphopteris, rather than uniting all Grammitidoids under Grammitis (Proctor, l.c.). The splitting of Hymenophyllum (Copeland, 1938, 1947) is, in the writer's opinion, an unnatural procedure. Trichomanes, Polypodium (exclusive of the Grammitidoids formerly referred to it), and Lycopodium are perhaps artificial genera when treated in their old, very wide circumscription, but too many segregates have been proposed, and before a general revision of the species 
is undertaken they can better stand as they are, in an inclusive sense. In the same way the genus Cyathea has been treated; the "single character" genera Alsophila and Hemitelia are, it is believed, justly rejected by most contemporary pteridologists, as long as no associated characters are found.

The sequence of genera in the Polypodiaceae is such that related genera are found side by side; where opinions disagree such resemblances have also been taken into account that spring to the eye but may eventually be shown to be without a natural basis.

Apart from the citations of the original descriptions of the species or transfers of the combinations only such papers have been cited that are of major importance for the floristics of the West Indian Pteridophytes or that contain more or less monographic treatments.

\section{B. Nomenclatural notes}

Xiphopteris serrulata (Swartz) Kaulfuss

This combination is usually cited as Kaulfuss, Enum. Fil. 85. 1824, for instance by Copeland (1952). In the indicated place Kaulfuss mentions the genus, but Grammitis serrulata Swartz is only listed as one of the constituent species, without actual transfer of the name. The valid combination is, however, found in the index (p. 300). The basionym is Acrostichum serrulatum Swartz, Prodr. 128. 1788.

Thelypteris tetragona (Swartz) Small var. guadalupensis (Fée) Kramer, comb. nov.

Basionym: Goniopteris guadalupensis Fée, lle Mém. 64. 1866.

This combination, previously published under Polypodium and Dryopteris, is new under Thelypteris.

Blechnum striatum (Swartz) G. Christensen, Index Filicum 160. 1906 (basionym: Onoclea striata Swartz, Syn. Fil. 304. 1806); not of R. Brown, Prodr. Fl. N. Holl. 152. 1810.

This is one of several cases in Christensen's Index Filicum where a name is adopted in spite of the presence of an earlier homonym, only because its basionym is oldest. The same work lists two synonyms of the present species, Lomaria tuberculata J. Smith and (in the Corrigenda of the first supplement) Lomaria ryani Kaulfuss. BRoADHuRsT (1912) in addition listed Lomaria brasiliensis Raddi as a doubtful synonym. The last name is, of course, not available under Blechnum because of Blechnum brasiliense Desvaux; it is also very doubtful whether it applies to the same species. The name Lomaria tuberculata, as I was very kindly informed by Mr. F. Ballard, Kew, was not published with a description, nor could a type specimen be found in the herbarium of the British Museum. The type of Lomaria ryani Kaulfuss in the same herbarium was examined for me by Mr. W. Punt, Utrecht, to whom I am much indebted for this service. As was already suspected after a scrutiny of the description, it differs in two important characters from the species under consideration, namely, the strongly falcate 
pinnae and the pubescence of the costae, especially on the adaxial side. The name $L$. ryani applies therefore to another species. Since the author does not recognize the genus Struthiopteris, under which the epithet striata could be used, as distinct from Blechnum, a new name is required:

Blechnum nesioticum Kramer, nom. nov.

Type (the type of Onoclea striata Swartz) from St. Christopher (St. Kitts) in herb. S-PA!

\section{Phytogeographical remarks}

As will be seen from the taxonomic treatment, not only a certain number of species hitherto unrecorded from the Dutch West Indies are included, but many amendments had to be made to Boldingh's accounts $(1909,1913)$, with respect to the nomenclature employed as well as in terms of corrections of identifications. There is no need to go into this subject in detail, as the notes on synonymy will provide sufficient information.

At present 74 native species of Pteridophytes in 32 genera are known from the Dutch West Indies. As the number of species found in the "Leeward Group" (Aruba, Curaçao, Bonaire) is very small, only 8 species in 8 genera, they will not further concern us here. It may be remarked in passing that in the Dutch Islands the Schizaeaceae (Anemia and Lygodium with one species each) and the Marsileaceae (one species of Marsilea) are confined to the Leeward Group; the last-named represents the only case of near-endemism, Marsilea ernestii A. Braun being apparently only known from Bonaire and the vicinity of Caracas, Venezuela.

The "Windward Group" (Saba, St. Eustatius, St. Martin) possesses 70 species in 28 genera. ${ }^{1}$ ) It is somewhat surprising that the smallest island, Saba, has the largest number: 57 species in 22 genera, whereas St. Eustatius has 32 species in 18 genera, and the largest island, St. Martin, only 15 species in 8 genera. This is, however, readily explained by the physiography of the islands. Saba reaches the highest elevation $(900 \mathrm{~m})$, and a number of species are confined to its highest peak, the Mountain. Thus tiny Saba $\left(12 \mathrm{~km}^{2}\right)$ in terms of the fern flora compares quite favourably with the neighbouring but much larger and also loftier island of St. Kitts (ca. $160 \mathrm{~km}^{2}$, over $1300 \mathrm{~m}$ ), which according to Box \& Alston (1937) has 97 species of Pteridophytes. Dominica, on the other hand, in the group of oldest and highest islands of the Lesser Antilles, with ca. $730 \mathrm{~km}^{2}$ and an elevation of up to ca. $1450 \mathrm{~m}$, has a Pteridophyte flora of nearly 200 species (HodGe, 1954).

The genera with the largest number of species are Polypodium (11), Thelypteris (8), Asplenium (6), Elaphoglossum and Lycopodium (4), Cyathea (sens. lat.), Hymenophyllum, Selaginella, and Pteris (3). Cyathea is, strangely enough, almost restricted to Saba; $C$. arborea occurs also on St. Eustatius but seems to be quite rare. The three species of tree-ferns

1) Varieties are disregarded in these and the following figures. 
of the Dutch islands are the same as those found on St. Kitts. Hymenophyllum and Selaginella are confined to Saba; Trichomanes and Lycopodium are also present on St. Eustatius, each with one species which is absent from Saba.

Floristically the most interesting species of the Dutch islands is probably Lycopodium wilsonii Underw. \& Lloyd, described from Puerto Rico, later reported from Guadeloupe and Colombia, and very recently collected in Suriname; some fragments were found among a rather old collection of $L$. setaceum from Saba.

While the physiography of the non-volcanic island St. Martin is unfavourable to the growth of ferns, the volcanoes of Saba and St. Eustatius possess plant communities where a number of epiphytic and terrestrial species flourish. Yet it is surprising that in spite of their proximity there is such a difference in their fern flora, though the larger number of species on Saba is explained by its higher elevation. Thus it is difficult to understand why the widespread species Polypodium pectinatum occurs on St. Eustatius but on Saba is replaced by its equally widespread relative $P$. plumula; why Saba has Lycopodium taxifolium (as well as two other species), St. Eustatius only $L$. dichotomum, etc. In some instances incompleteness of our knowledge of the flora may account for the seemingly random distribution of species over these islands; but collecting has been relatively quite intense on these small islands and this explanation hardly holds good in all cases. Likewise, the absence of other widespread species that occur on many adjacent islands, such as Hypolepis repens and Lycopodium cernuum, is rather astonishing.

When the 70 species of the Windward Group are arranged according to their pattern of general distribution, the following figures are obtained:

Tropics of the New and at least parts of the Old World. . . . 9 species Throughout the American Tropics (sometimes also Subtropics) ${ }_{\text {Circum-Caribbean (i.e., Greater and Lesser Antilles, Central and }}$

South America, sometimes also Florida) .........

Antilles and Central America . . . . . . . . . . .

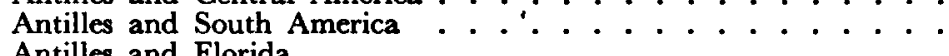

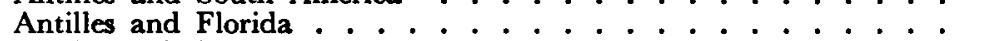

Antilles only ${ }^{1}$ ) . . . . . . . . . . . . . . . . . .

Lesser Antilles only . . . . . . . . . . . .

$\begin{array}{rl}9 & \text { species } \\ & \Rightarrow \\ 9 & \\ 2 & \prime \\ 5 & \prime \\ 2 & " \\ 9 & " \\ 5 & "\end{array}$

Species with a very wide distribution form more than one-half of the fern flora which therefore can be said to show a lack of peculiarity. Among the species with a more limited area those with an Antillean distribution are relatively more numerous on Saba (11 out of 57) than on St. Eustatius (4 out of 32); species with a Caribbean distribution (West Indies and adjacent parts of Central and/or South America) are equally distributed over both islands (16 out of 57 on Saba, 9 out of 32 on St. Eustatius, that is approximately 2/7 in

2) Mainly in the Hymenophyllaceae, Selaginella, and Elaphoglossum. 
both cases). For St. Martin the absolute numbers are too low for such calculations. Likewise it is impossible to conclude from the distributional patterns whether the floristic influence from the South (Lesser Antilles, South America) or from the West (Greater Antilles, Florida, Central America) is strongest, though this may be possible when the whole flora of the islands is taken into account, as was done to a certain degree by SToFfers (1956). The matter is of interest in connection with the problem whether the Lesser Antilles are to be regarded as oceanic islands or not (see Chrysler, 1948, and BEARD, 1949).

\section{ACKNOWLEDGMENTS}

The author is very much indebted to Mr. C. V. Morron, Washington, D.C., for help with the identification of problematic specimens, especially in Hymenophyllum, Thelypteris, and Elaphoglossum; to Mr. F. BALLARD, Kew, for assistance in connection with a nomenclatural problem, and to the Directors of the Herbaria of Leiden and Stockholm for loan of material.

\section{REFERENCES}

BeARD, J. S. 1949. The natural vegetation of the Windward and Leeward Islands. Oxford For. Mem. 21. Oxford.

Boldingr, I. 1909. The Flora of St. Eustatius, Saba and St. Martin. Leiden. 1913. Flora voor de Nederlandsch West-Indische Eilanden. Amsterdam.

Box, H. E. and A. H. G. Alston. 1937. Pteridophyta of St. Kitts. Jo. Bot. 75: 241.

Broadhurst, J. 1912. The genus Struthiopteris and its representatives in North America. Bull. Torr. Bot. Cl. 39: 257; 357.

Chrysler, M. A. 1948. Origin of the West Indian fern flora. Am. Fern Jo. 38: 135.

Copeland, E. B. 1938. Genera Hymenophyllacearum. Philipp. Jo. Sci. 67: 1 . , 1947. Genera Filicum. Chronica Botanica, Waltham, Mass.

1952. The American species of Xiphopteris. Am. Fern Jo. 42: 43.

Hodge, W. H. 1954. Flora of Dominica, B.W.I. Part I. Lloydia 17: 1.

Morton, C. V. 1950. Notes on the ferns of the eastern United States. Am. Fern Jo. 40: 213 sqq.

Pichi-Sermoli, R. E. G. 1959. Pteridophyta. Vistas in Botany, London.

Proctor, G. R. 1953. A preliminary checklist of Jamaican Pteridophytes. Bull. Inst. Jam. Sci. 2. 5: 1.

Stofrers, A. L. 1956. The vegetation of the Netherlands Antilles. Thesis, Utrecht. 